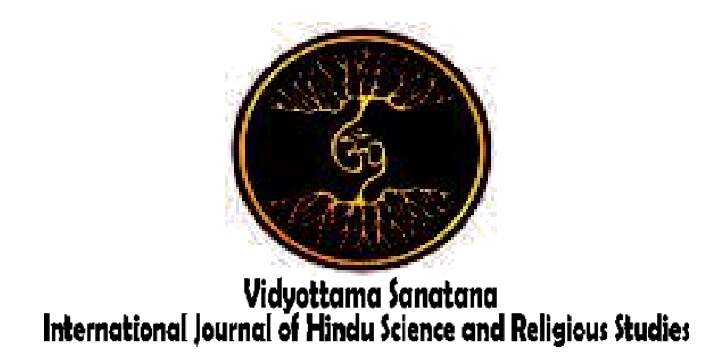

Vol. V No. 1 June 2021

\title{
DISINTEGRATION AMONG WOMEN: HINDUS WOMEN' CHALLENGES IN BUILDING SUKINAH FAMILY
}

By:

Ida Ayu Alit Maharatni; I Ketut Suda; Ni Wayan Karmini

Universitas Hindu Indonesia

maharatni@gmail.com; suda.unhidps@yahoo.co.id; karmini.niwayan@yahoo.com

Received: February 11, 2021

Accepted: March 17, 2021

Published: June 30, 2021

\begin{abstract}
Subordination of women becomes a question in carrying out the household dish, especially the care for children who are born, which is the responsibility of husband and wife. It is impossible for the Sukhinah family to be formed if the burdens, both domestic and social, are not matched equally between men and women. Like a pillar in a house, if the load is not the same, not only will one of the pillars be destroyed but the house itself will collapse, if that is the case then the sukhinah family is the goal of every Hindu marriage, namely a happy and prosperous marriage that will not be realized. In fact there are divorce cases that have occurred in Denpasar City, divorce cases for Hindu couples in general have increased, namely in 2013 as many as 297 cases, in 2014 as many as 326 cases, 2015 as many as 315 cases, in 2016 as many as 418 cases, in 2017 as many as 495 cases, and in 2018 there were 566 cases. Based on the above phenomena, the author wants to explore the potential problems faced by Balinese Hindu women when carrying out domestic, public and social roles (traditional krama) in building a sukhinah family. It seems that women have problems adapting well to their husband's family environment because of differences in paradigms, different parenting styles and differences in habits. The factors causing the challenges faced by Balinese Hindu women in Denpasar City actually arise from the vertical relationship between women.
\end{abstract}

Keywords: Disintegration Among Woman; Hindus Family, Patriakhi, Hindus Woman.

\section{INTRODUCTION}

Patriarchy according to (Bressler, 2007 ) is a social system that places men as the main central authority figure in social organization. Fathers have authority over women, children and property. Implicitly this system institutionalizes men's governance and privileges and demands the subordination of women. Furthermore, Bressler details patriarchy as a concept used in the social sciences, especially in anthropology and femininity reference studies. Patriarchy also means the distribution of power between men and 
women, where men have superiority in one or more aspects, such as lineage determination (exclusive patrilineal descent and carrying last name), firstborn rights, personal autonomy in relationships. social, participation in public and political or religious status or the attribution of men's and women's jobs is determined by the sexual division of labor.

This then results in men obtaining privileges or privileges based on their gender, men then occupying a seat of power in the structure of society, and ironically society accepts it as something that is taken for granted. The understanding that women have to stay at home to take care of the household is accepted as something that should be, this certainly shows that an ideological process has taken place which is responsible for the change from history to something as natural as it should be, becomes a myth and is supported. by discourse dominated by men.

This myth is accepted and supported by the socio-cultural structure of society, women are domesticated and men have full authority in the public sphere. This real situation in society makes efforts to uncover gender injustice often interpreted as a rebellion against the existing order. In the development of a patriarchal culture, gender ideology creates injustice where women are victims. It seems as if women only have a domestic sphere, but this is not the case in public spaces. Various justifications are made, so that the view is correct and cannot be changed. As a result, men always lead and women are led. So this implies a process of decline that afflicts women (Gandhi, 2002).

Subordination of women becomes a question in carrying out the household dish, especially the care for children who are born which is the responsibility of husband and wife. It is impossible for the Sukhinah family to be formed if the burdens, both domestic and social, are not matched equally between men and women. Like a pillar in a house, if the load is not the same, not only will one of the pillars be destroyed but the house itself will collapse, if that is the case then the sukhinah family is the goal of every Hindu marriage, namely a happy and prosperous marriage that will not be realized.

The research (ARIFIANTI, JAYANEGARA, GANDHIADI, \& KENCANA, 2017) states that domestic violence cases in Denpasar from 2012 to 2015 are as follows: number of domestic violence cases in 2012: 1100 families, in 2013: 970 families, in $2014: 710$ families, and in 2015: 660 families, so that is an average of 860 families. Arifianti et al explained that there are factors that trigger domestic violence in Denpasar City, namely: (a) the quality of the social relations of the perpetrators, (b) the characteristics of the perpetrators' work, (c) past experiences, (d) supporters of domestic violence, (e) the home economy stairs, and (f) time with family.

This domestic violence case is certainly very influential on the divorce rate of Hindu families in the city of Denpasar, referring to data from the Denpasar District Court Class I A. Divorce cases for Hindu couples in general have increased, namely in 2013 as many as 297 cases, in 2014 as many as 326 cases, in 2015315 cases, in 2016 as many as 418 cases, in 2017 as many as 495 cases, and in 2018 as many as 566 cases, so that the total divorce cases handled by the Denpasar District Court Class IA in the last six years were 2,417 divorce cases (Civil Case Sheet Hindu Couple Divorce at Denpasar District Court Class IA: 2018). The divorce case data shows how fragile the marriage bond is built by Hindu families.

Based on the above phenomena, the writer wants to explore the potential problems faced by Balinese Hindu women when carrying out domestic, public and social roles (customary manners). Interpreting any incidents that are not pleasing to both in family life, work environment and when interacting with 
customary manners then bring them to a position of awareness so that women can see brightly the crushes of emotions they face. Like icebergs, there are strong emotional struggles at the bottom before they actually surface before ending in domestic violence or divorce. So that a Balinese Hindu woman is able to face the challenges of forming a Sukhinah family in Denpasar City.

\section{METHOD}

This research is a phenomenological research. The phenomenon studied is the condition of the domestic, public and social sectors (traditional krama) which is a challenge for Balinese Hindu women in forming a sukhinah family in the city of Denpasar. Meanwhile, the paradigm that will be used by researchers in this research is the critical emancipatory knowledge paradigm. Paradigm that reveals and analyzes social reality by questioning the imbalance of existing social relations. Research in a critical paradigm views reality as not in harmony but tends to be in situations of conflict and social struggle. (Djamba \& Neuman, 2002) affirm the assumption of critical social research that social reality is always changing and that change is rooted in various tensions, conflicts, or contradictions in social relations or institutions. This research was conducted in Denpasar City. The city of Denpasar was chosen as the research location with several considerations, among others: First, based on a preliminary study conducted by the researcher, there were conditions that were relatively difficult for Balinese Hindu women in Denpasar to experience which led to divorce. Second, based on data from the Office of Social Affairs, Women's Empowerment and Child Protection in the Province of Bali, it is recorded that Denpasar City has the highest number of violence against women as shown in the following data: Denpasar City with 63 cases; Tabanan as many as 44 cases; Badung as many as 17 cases; Gianyar as many as 13 cases; Klungkung as many as 7 cases; Buleleng as many as 5 cases; Jembarana as many as 5 cases; Karangasem as many as 1 case; and Bangli with zero cases.

Third, based on data on divorce in Denpasar City, it occupies the highest position in Bali Province. Divorce data compiled by the Regional Office of the Provincial Ministry of Religion in 2019 are as follows: Jembarana as many as 201 cases; Tabanan as many as 62 cases; Badung as many as 186 cases; Gianyar as many as 32 cases; Klungkung as many as 20 cases; Bangli as many as 8 cases; Karangasem as many as 21 cases; Buleleng as many as 118 cases; and Denpasar City with 563 cases. Data were collected by means of observation, interviews, literature study and document study.

\section{RESULT AND DISCUSSION \\ 3.1 Role Dysfunction in the Family}

Article 31 paragraph (1-3) states that the rights and position of the wife are equal to the rights and positions of the husbands in household life and in social life together in society. The parties have the right to take legal actions. The husband is the head of the household and the wife is the housewife. Implicitly, this article describes husband and wife as the initial relationship in the family. The husband and wife relationship provides the foundation and determines colors for all relationships in the family. Many families fall apart if there is a failure in the husband and wife relationship. Husband and wife relations as a balanced duality in building a sukhinah family. This matter seems to be left out in a patriarchal culture, because the framework itself is determined by men while women must accept. The reality in the field, husband and wife as a complementary duality have not been manifested completely and completely, especially in the Hindu family in Denpasar, so that role dysfunction appears as a form of challenge faced by 
Hindu women in forming a sukhinah family. (male) in various forms. First, men's ignorance of Balinese Hindu women when giving birth to children, so that the wife experiences baby blues. Second, men's inability to meet family needs. Third, the imbalance in the division of domestic roles in the family. Such conditions make Balinese Hindu women as agents trying to provide control over men, because according to Giddens, agents are not always subject to structure, but agents can carry out various activities to reproduce new structures in order to catch up by filling themselves up, working with quality, communicating. and cooperate without dominating men. This is in line with the principles of Hindu feminism which are based on the concept of Ardhanareswari. This concept reveals that men and women have an equally important role, are interrelated, influence each other and form a complete unity as the concept of duality put forward by Giddens to show how important cooperation is in playing the role between Balinese Hindu women and men. in forming a sukhinah family.

\subsection{Disintegration Among Woman}

In the previous sub-chapter, it was discussed clearly how patriarchy is present in Balinese Hindu society which places men as the center of a family. This patriarchal system has been put forward by Bachopen as part of the evolutionary stage of the family. Bachopen (Suda, 2008) explains that in a patriarchate system, men are not satisfied with the existing system, then when they get married then take prospective wives from other groups and bring them to their group. Thus the children who were born also remained in the male group. This situation evolutionarily led to the emergence of family groups with the father as the head of the family. These postulates have led to the marriage system in Bali which includes women into the husband's family clan, following the position and social status of the husband's own family. This reality is in line with the opinion (Hemamalini \& Suhardi, 2015) which emphasizes that in a marriage in Bali by adopting a patriarchal system, a woman is released from her legal relationship with her original family and then totally enters her husband's family. Thus, a girl who is already married is no longer taken into account for her rights and obligations, material and immaterial in her original family, but is fully counted in her husband's family. Even in indigenous communities in Bali, usually one boy who is married stays in the housing complex of his parents.

This understanding refers to the reality that some families in Bali still choose to live together with their extended family in one environment, divide living areas in one natah, gather and interact with in-laws, in-laws, and even relatives of the husband's family. Women meeting other women with diverse backgrounds, such as culture, education and parenting, often cause problems, as stated by Alit Putrawan, an academic as well as a PHDI administrator for Bali Province as follows;

Make no mistake, many surveys and studies prove that many families are destroyed because of the entry of women into the family with different traditions and circumstances. For example, I have 7 brothers, my brother-in-law is from Buleleng, Negara and so on. For those in Buleleng, they are the Buleleng method, the Gianyar method, the Karangasem method, they forget that they live in Denpasar and the traditions that apply in the family are traditions like Denpasar. Because his wishes in Buleleng are not accommodated, Gianyar and Karangasem are not accommodated, especially those in Java, so small sparks arise, namely that there are lies between us. Things like this are what break the relationship between families, the feeling of "I am ostracized by the family, sing agrees, sing nyak taen anggone", they finally leave because they cannot copy the traditions that exist in the 
family, dive into that tradition, but they still carry the tradition of the house (interview, 9 December 2020).

Alit Putrawan's statement above illustrates how the patriarchal cultural structure controls Balinese Hindu women in the male family. Observing such conditions, Derrida (Lubis, 2016) doubts the possibility of a law or system that is general and universal. Derrida rejects the structuralist view that destroys the role of the subject (anti-humanist and existentialist). The structure is determined by the subject, so structure and meaning can change based on time and context. Derrida also rejects the view that it is thought that structure and rationality alone determine meaning, so that if he returns to highlighting the statement of informant Alit Putrawan, it shows that the male family is seen as a structure, so tradition must be prioritized, while Balinese Hindu women appear as subjects who want to be accommodated. values obtained previously through the learning process. Instead of finding meaning in the relationship between men and women as two equal sides, a structure that turns off the role of the subject is thick, where men require women to follow the traditions of their families. Subjects (Balinese Hindu women) may seek meaning by disagreeing with the situation, negotiating because it is not only the structure that can determine meaning so that Hindu Balinese women face the possibility of leaving the existing regulations.

The denial by Balinese Hindu women as subjects to the prevailing structure has implications for the divorce of Hindu couples at the Denpasar District Court Class I A. Divorce cases of Hindu couples in general have increased during the last five years, namely in 2013 as many as 297 cases, in 2014 as many as 326 cases, in 2015 as many as 315 cases, in 2016 as many as 418 cases, in 2017 as many as 495 cases and in 2018 as many as 566 cases. It can be suspected that domestic violence against women occurs because women tend to lack compliance with structures, resulting in male families as power owners feel entitled to commit deviant actions and lead to violence, this is stated in the data published by DP3A Bali Province in the semester one year 2020, which shows that Denpasar City recorded the highest cases in Bali Province with 63 cases of violence, specifically detailed as follows; 21 cases of physical violence, 30 cases of psychological violence, 4 cases of sexual violence and neglect and others 32 cases. Domestic violence in Denpasar City is above the rate of violence in other districts in Bali, such as Tabanan with 44 cases, Badung 17 cases, Gianyar 13 cases, Klungkung 7 cases, Jembrana 5 cases, Kangasem 1 case while Bangli reported no domestic violence. in semester 1 of 2020.

The data on violence that led to divorce show that Hindu families have slowly degraded over time. This condition is in line with research (Mahyuni, 2016)which reveals that the emergence of the issue of domestic violence (KDRT) often leads to divorce. For him, this phenomenon raises the question, is it not true that violence against women or divorce is not justified by Hindu teachings, as stated in the following book Manava Dharmaśastra:

tathā nityam yateyātam
strīpumsau tu kitakriyau,
yathā nābhicaretāṇ tau
wiyuktāwitretanam

(Manava Dharmaśastra, IX.102)

Translate:

Men and women who are bound in marriage should try not to tire themselves out so that they don't divorce and don't want to violate the loyalty of one another (Pudja, 2000). 
Referring to the above verse, Hinduism actually glorifies marriage as the starting gate in the cycle of entering married life. However, in reality the sacred values in the Hindu marriage bond seem to collapse due to various household problems, ranging from mental readiness problems of the two partners, economic problems, reproductive health problems, even the problem of incompatibility between family members resulting in disintegration between women caused by women. not being able to adapt to traditions in her husband's family environment can trigger discord in the household. The same thing is also stated by (Matondang, 2014) that in poor family interaction patterns, it will cause differences of opinion, quarrels, arguments, disputes that continue to cause loss of love and affection. Quarrels lead to sowing hatred and prejudice towards spouses or other family members such as in-laws and in-laws. A similar condition was expressed by Kumala, an informant who stated that there were seeds of disputes with her parents-in-law regarding childcare as in the following interview. Initially the dispute started when my child was born. So, I started raising children. Now, to my surprise, my mother-in-law (meaning the grandmother of my child) felt the greatest feeling about being a child. Even though he was not there to help me anything. At that time, I was not an expert in taking care of babies. But I, with the position in my husband's family as son-in-law, try to learn from the books I read. But my mother-inlaw, is still stiff by sticking to her experience of taking care of babies, yes, you can count the last time I handled the baby 40 years ago, but it still wants to be applied now. Actually it's okay, I just feel a lot of intimidation and often say like this "huh ... how come the child is crying, how come, how come" and so on (Interview, 4 December 2020).

Based on the statement given by Kumala above, it can show that there have been sparks of disputes between women, because one does not want to adapt. This disintegration between women began to emerge because there were different paradigms of parenting for children. On the one hand, Kumala's parenting was obtained through reading books on the latest parenting according to the times, while on the other hand her mother-in-law adhered to a pure parenting pattern based on her knowledge and experience when caring for her children first. In this context, Kumala's mother-in-law has the power to know about parenting. This condition for Foucault (Beilharz, 2018) is the effect of power relations, which means that power is always actualized through knowledge and knowledge always has a power effect. All knowledge enables and guarantees the operation of power, so that one person can control another human being, in this case it is shown by the domination of women over other women.

This condition seems to have been predicted beforehand by (Setianti, Wiguna, \& Setiawan, 2017)who said that the relationship between mother-in-law and daughter-in-law has been identified as a relationship that experiences conflicts in many relationships in extended families. This means that the daughter-in-law is required to be able to adjust to the ego of the mother-in-law because she is considered more experienced or has a longer family life. According to Bourdieu (Burnama, Krisdinanto, \& Yoanita, 2014) this situation is part of social practice by playing with the social capital owned by the in-laws. The social capital in question is all kinds of relationships as a resource for determining social position in the family. This social capital is actually a valuable social relationship between people. In turn, lead other individuals, namely the daughter-in-law, to take reinterpretative actions against the wishes of their motherin-law. In line with this statement, A. A. Sudiana as the observer who is the Chair of the Denpasar City MDA stated the following. 
Refrain, both husband, wife, in-laws and in-laws. A condition where all parties have mutual ego, it is easy to cause conflict in the family (interview, 13 December 2020)

This conflict is very susceptible to being awakened because of the strong sectoral ego held by the mother-in-law in the line of structure, so that it is a factor that causes Balinese Hindu women to face challenges in forming a sukhinah family in Denpasar City. A form of that challenge is the disintegration between women, which was again manifested from the results of Kumala's interview as an informant who lives under the same roof as her mother-inlaw. Among his various statements he said:

Sometimes as a daughter-in-law in this house I feel tired, because I stay up late putting my child to sleep all night, in the morning my mother-in-law wakes up early and asks for a shower, to eat, even though I need sleep more. As if I accepted it was done, even though I could do it after resting enough. Little things like that make me emotional soul (Interview, 4 December 2020).

Based on the conditions experienced by Kumala, a Hindu woman who was appointed as an informant, a frame of mind can be built that the interaction between women in the family is prone to disputes due to differences in habits that are owned by both parties, both from mother-in-law or daughter-in-law at home. the. For (Fitroh \& Oktavianingsih, 2020) a daughter-in-law who lives at the mother-in-law's house absolutely requires a high level of hardiness, which is to have high immunity and be able to face existing problems and be able to solve problems properly by adapting to existing traditions. they live. Daughters-in-law who live in the motherin-law's house have a greater potential for problems that can cause stress every day if the relationship with the mother-in-law is not good.
Related to this, Suntrock (Fitroh \& Oktavianingsih, 2020) explains that hardiness is a personality characteristic that has a function as a source in helping individuals to adapt to all demands or pressing conditions that can cause stress. Three aspects that are owned, namely commitment, control and challenge. First, commitment is a big belief in him who wants to form his family as a whole and harmoniously. So, in any condition that is felt at the mother-in-law's house that can cause conflict in her family, the daughterin-law can easily overcome it because this condition is interpreted as an interesting challenge to live with, done with all my heart and enthusiasm. Second, control is the ability to always be in a strong condition when experiencing stressful conditions at the mother-in-law's house, to continue to survive, not to give up and to have the confidence that everything can be resolved well. Third, the challenge is an attitude of self-acceptance to sincerely accept the changes that occur in his life. These three aspects are shared by the daughter-in-law, so that they can contribute greatly to a source of self-defense and good adaptability. Kumala, an informant who has experienced disintegration with her motherin-law has done something similar in the following narrative.

Maybe for me he is good for his circle, but not suitable, because our mindset and upbringing and habits are different. But our relationship with our in-laws is fine, but the conflicts we have experienced are still persistent. Sincerity is wasted, in my condition there are other people who saw it saw how I was treated, how my sincerity was wasted. I don't want to (anymore) give my heart. I try to believe that everything can be discussed well, I have to be able to control emotions and I try to be sincere for the happiness of my little family (interview, 4 December 2020). 
With regard to the above statement, a framework of thought can be built that Balinese Hindu women in the city of Denpasar are prone to disintegration between women because of the ego which is based on differences in thought patterns, parenting styles and habits between daughter-in-law and mother-in-law, so that the daughter-in-law is expected to be able to do so. adaptation to new situations.

These situations refer to Derrida's basic premise (Suda, 2008) which denies the opposition to speech or writing, whether it exists or does not exist, is pure or tainted and in the end is a rejection of a single truth or logos itself. In accordance with the essence of the deconstruction itself, namely dismantling the ideology behind the social text (actual human behavior) which will have an impact on the adjustment of the daughter-in-law to the mother-in-law in society, Hindu women in Denpasar City need to form a sukhinah family as said by Mintarini, a housewife. households, workers and play an active role as manners for the wife in social activities in the banjar as follows.

\begin{abstract}
At that time, I immediately jumped into the banjar, because my in-laws have never been to the banjar. So far, most of those who go to the banjar are servants, since my fatherin-law continues to work, because he has a career, so he often carries out activities in Jakarta-DenpasarJakarta, so rarely at home, so that the shady is a servant. When I worked as a krama wife in the banjar, they (the wife's krama in the banjar) wanted me to be better than my parents-in-law, who at that time relied on maids for my fatherhood (Interview, 4 December 2020).
\end{abstract}

Based on the interview quote above, it can be stated that the presence of the son-in-law not only completes domestic and public tasks, but also customary duties as wife's karma in the banjar. For Mintarini, one of the informants in this study, social roles require an adjustment to the norms or duties imposed by adat on Balinese Hindu women in the city of Denpasar. The process of adjustment is not easy, this is because in human life there are always new life patterns that apply in general society and in the nuclear family, because they are vulnerable to conflicts that are focused on interactions between women such as conflicts with sister-in-law and with female in-laws. This was stated by Mintarini, an informant who is a housewife who lives with her in-laws and big family in one natah as follows.

I live in one natah with my extended family, with my in-laws and in-laws. Honestly, I have had conflicts with my sister-in-law who is a woman, they even had an ally to scourge me in the house of my husband's family. They didn't like my husband, but they cornered me. They cornered me, tried me like a defendant because my husband at that time obtained an inheritance from the sale of family land, where they (sister-inlaw, husband's brother) asked for a share.

Because it was done continuously until I couldn't stand it and I had decided to leave the house, but my biological mother didn't allow it. I persisted even though I had to hear bad things from them (in-laws and in-laws) (Interview, 4 December 2020).

The conditions experienced by Mintarini indicate that the potential for interaction conflicts between women is very vulnerable to occur when they are in one large family room (a natah). This condition does not rule out the existence of an alliance between women which contains intrigues to destroy the harmony in the family. This is also a form of challenge in terms of guest houses that must be faced by Balinese Hindu women in forming a sukhinah family in the 
city of Denpasar. Therefore, (Hayati \& Hayati, 2011) argues that when an individual decides to get married and become a husband and wife partner, the first thing that will be discussed by the couple is the place to live for their new family (new local). Spouses are free to decide where to live. There are couples who choose to stay with their parents, while there are couples who decide to break away from the parent family to live independently to form their new family. As experienced by Pramiyanti, an informant who left her extended family and decided to live independently only with her nuclear family as stated in the following interview excerpt.

The pillar at the beginning of the marriage has been emphasized, when you want to go to the raga castle you have to first hang out. Poles tried to accept that yes that was what I had to do. Obviously at that time I only needed support from my husband, because there must have been flicks from my in-laws and in-laws. Thankfully the poles can adapt quickly. But it is even more grateful to be able to live outside the castle, so for the nika pole is the only way to reduce conflict, because of course there will be disputes if Sareng lives with a large family (interview, 6 December 2020).

The opinion above illustrates that ideally in one house there is only one family with one head of the family, namely the husband as the structure holder in the family. This can be used as an anticipation so that there will be no conflict between son-in-law and in-law, son-in-law and even brother-in-law because of the struggle for positions and roles in the house. Domestic life will be more perfect, when the couple has their own house, so they can manage their own household and family freely without interference from other parties. This is important, because according to
Glasser (Hayati \& Hayati, 2011) that there are four psychological needs that must be fulfilled, namely love and belonging, power, freedom and fun. The four needs, will be a hope for the in-laws, in-laws and in-laws to both be able to occupy a safe position. However, when they live together, the four needs will be fought over each other.

It appears in the condition of the daughterin-law who lives at the mother-in-law's house, if she is unable to position herself properly (read: adaptation) then the daughter-in-law automatically becomes inferior in achieving her needs. However, it would be different if you did not live with your mother-in-law, so there would be no parties involved, so that the four needs would be able to run in balance. This is in line with Derrida's principle of thought (Barker, 1999)) that the logocentrism thinking tradition is the most relevant to be used to study cultural and structural inequalities due to gender differences. In particular, deconstruction means dismantling hierarchical binary oppositions which function to ensure the truth by denying inferior partners so that relations between women are dialectical, which means that Balinese Hindu women in the city of Denpasar today contribute by interacting positively in the family to be accepted. openly by the family environment, so that they can form a sukhinah family. Based on the above review, it can be concluded that disintegration between women is a factor that causes Balinese Hindu women to face challenges in forming a sukhinah family in the city of Denpasar, because it can be a source of conflict in the family. The factors that cause these challenges, among others: first, disputes due to differences in thinking patterns (paradigms), differences in parenting styles and differences in habits of daughter-in-law and mother-in-law as determinants of structure because they consider their knowledge and experience as the basis of power by playing social capital 
owned so that his daughter-in-law can be a reinterpretation of himself. Second, the alliance between women and in-laws can destroy the harmony of the family order, so it is necessary to dismantle hierarchical binary oppositions which function to guarantee the truth by denying inferior partners by deciding to live independently with the nuclear family to avoid sources of conflict in order to create harmony in order to form a sukhinah family in Denpasar City.

\section{CONCLUSION}

One of the factors that causes Balinese Hindu women to face challenges in forming a sukhinah family in the city of Denpasar is that women are not able to adapt well to their husband's family environment due to differences in mindset (paradigm), differences in parenting styles and differences in habits. This condition occurs due to the vertical relationship between women. Which is not well-established, women are not only the object of the subordination of men, but also become the subject of subordination to other women. The theoretical findings in this study show that the theory of power relations is in line with the realities faced by Hindu women in the city of Denpasar, but there are differences where power in the Balinese Hindu family is not only owned by men, but the elders in the family such as power of attorney of women in law to daughter in law the girl.

\section{REFERENCE}

ARIFIANTI, L. A. A., JAYANEGARA, K., GANDHIADI, G. K., \& KENCANA, E. N. (2017). IDENTIFIKASI FAKTOR-FAKTOR PEMICU KEKERASAN DALAM RUMAH TANGGA DI KOTA DENPASAR. E-Jurnal Matematika. https://doi.org/10.24843/mtk.2017.v0

\section{6.i01.p151}

Barker, D. (1999). Motheres, babies and health in later life. Public Health. https://doi.org/10.1016/s00333506(99)00170-5

Beilharz, P. (2018). Modern and postmodern. In Routledge Handbook of Cultural Sociology: Second Edition. https://doi.org/10.4324/97813152677 84-16

Bressler, C. E. (2007). Literary Criticism: An Introduction to Theory and Practice 4th-ed. Pearson Education.

Burnama, G., Krisdinanto, N., \& Yoanita, D. (2014). Stereotyping Risma: Pembingkaian Sosok Tri Rismaharini Di Majalah Detik Dan Tempo. Jurnal Scriptura.

Djamba, Y. K., \& Neuman, W. L. (2002).

Social Research Methods: Qualitative and Quantitative Approaches. Teaching Sociology. https://doi.org/10.2307/3211488

Fitroh, S. F., \& Oktavianingsih, E. (2020). Peran Parenting dalam Meningkatkan Literasi Kesehatan Ibu terhadap Stunting di Bangkalan Madura. Jurnal Obsesi : Jurnal Pendidikan Anak Usia Dini.

https://doi.org/10.31004/obsesi.v4i2.4 15

Gandhi, M. (2002). Kaum Perempuan dan Ketidakadilan Sosial. Yogyakarta: Pustaka Pelajar.

Hayati, F., \& Hayati, F. (2011). Pesantren: Suatu Alternatif Model Lembaga Pendidikan Kader Bangsa. MIMBAR, Jurnal Sosial Dan Pembangunan.

Hemamalini, K., \& Suhardi, U. (2015). DINAMIKA PERKAWINAN ADAT BALI. Dharmasmrti: Jurnal Ilmu 
Agama Dan Kebudayaan, 14(27).

https://doi.org/10.32795/ds.v14i27.45

Lubis. (2016). Pemikiran Kritis Kontemporer: Dari Teori Kritis, Culture Studies, Feminimisme, Postkolonial Hingga Multikulturalisme. Jakarta: PT.Raja Grafindo Persada.

Mahyuni, I. A. P. (2016). "Perceraian

Perempuan Bali dan Penyelesaiannya

Di Kota Denpasar: Kajian Berdasarkan Perspektif Gender". Universitas Udayana.

Matondang, A. (2014). Faktor-faktor yang
Mengakibatkan Perceraian dalam Perkawinan. JPPUMA: Jurnal Ilmu Pemerintahan Dan Sosial Politik UMA (Journal of Governance and Political Social UMA).

Pudja, I. G. (2000). Manawa Dharmasastra. Surabaya: Paramitha. Setianti, F., Wiguna, A., \& Setiawan, W. (2017). Pengaruh Lingkungan Keluarga Terhadap Minat Belajar Anak. Jurnal Paedagogie.

Suda, I. K. (2008). Anak dalam Pergulatan Industri Kecil dan Rumah Tangga di Bali. Yogyakarta: Aksara Indonesia. 